\title{
Wheat Yield Trend and Soil Fertility Status in Long Term Rice-Rice-Wheat Cropping System
}

\author{
Nabin Rawal ${ }^{* 1}$, Devraj Chalise ${ }^{1}$, Janmejai Tripathi ${ }^{2}$, Dinesh Khadka ${ }^{1}$ and Khim Thapa ${ }^{1}$ \\ ${ }^{1}$ National Wheat Research Program, Bhairahawa, Rupandehi \\ ${ }^{2}$ Soil Science Division, Khumultar, Lalitpur \\ *Corresponding author: nabin_rawal@yahoo.com
}

Received April 2015; Revised June 2015; Accepted July 2015

Scientific Editor: YG Khadka, TB Gurung

Copyright (C) 2015 NARC. Permits unrestricted use, distribution, and reproduction in any medium, provided the original work is properly cited

\begin{abstract}
A long-term soil fertility experiment under rice-rice-wheat system was performed to evaluate the long term effects of inorganic fertilizer and manure applications on soil properties and grain yield of wheat. The experiment began since 1978 was laid out in randomized complete block design with 9 treatments replicated 3 times. From 1990 onwards, periodic modifications have been made in all the treatments splitting the plots in two equal halves of $4 \times 3 \mathrm{~m}^{2}$ leaving one half as original. In the original treatments, recent data revealed that the use of Farm Yard Manure (FYM)@10 $\mathrm{t} \mathrm{ha}^{-1}$ gave significantly $(P \leq 0.05)$ higher yield of $2.3 \mathrm{t} \mathrm{ha}^{-1}$ in wheat, whereas control plot gave the lowest grain yield of $277 \mathrm{~kg} \mathrm{ha}{ }^{-1}$. Similarly, in the modified treatments, the use of FYM@10 $\mathrm{t} \mathrm{ha}^{-1}$ along with inorganic Nitrogen $(\mathrm{N})$ and Potassium oxide $\left(\mathrm{K}_{2} \mathrm{O}\right) @ 50 \mathrm{~kg}$ ha ${ }^{-1}$ produced significantly $(P \leq 0.05)$ the highest yield of $2.4 \mathrm{t} / \mathrm{ha}$ in wheat. The control plot with an indigenous nutrient supply only produced wheat yield of $277 \mathrm{~kg} \mathrm{ha}^{-1}$ after $35^{\text {th }}$ year completion of rice-rice-wheat system. A sharp decline in wheat yields was noted in minus $\mathrm{N}$, phosphorus $(\mathrm{P})$, Potassium $(\mathrm{K})$ treatments during recent years. Yields were consistently higher in the $\mathrm{N}: \mathrm{P}_{2} \mathrm{O}_{5}: \mathrm{K}_{2} \mathrm{O}$ and FYM treatments than in treatments, where one or more nutrients were lacking. The application of $\mathrm{P}_{2} \mathrm{O}_{5}$ and $\mathrm{K}_{2} \mathrm{O}$ caused a partial recovery of yield in $\mathrm{P}$ and $\mathrm{K}$ deficient plots. There was significant $(P \leq 0.05)$ effect of use of chemical fertilizers and manure on soil properties. The soil analysis data showed an improvement in soil $\mathrm{pH}$ (7.8), soil organic matter (4.1\%), total $\mathrm{N}$ content $(0.16 \%)$, available $\mathrm{P}\left(503.5 \mathrm{~kg} \mathrm{P}_{2} \mathrm{O}_{5}\right.$ ha $\left.^{-1}\right)$ and exchangeable $\mathrm{K}\left(137.5 \mathrm{~kg} \mathrm{~K}_{2} \mathrm{O}\right.$ ha $\left.{ }^{-1}\right)$ in FYM applied treatments over all other treatments. The findings showed that the productivity of the wheat can be increased and sustained by improving nutrient through the integrated use of organic and inorganic manures in long term.
\end{abstract}

Key words: FYM, inorganic, long term, organic and rice-rice-wheat

\section{सारांश}

धान-धान-गहुँ वाली प्रणालीमा रासायनिक र प्राङ्रारिक मलको वाली उत्पादन र माटोको उवर्रकतामा पर्न सक्ने दिर्घकालिन असरको शोधकार्य लागी सन् १९७६ देखि राष्ट्रय गहुँ वाली अनुसन्धान कार्यक्रम भैरहवामा एक परीक्षण शुरु गरिएको थियो । उक्त परीक्षण रेन्डोमाईज्ड कम्पीलीट ब्लक डिजाईनमा तीन पटक छुट्टाछुट्टै गरिएको थियो। सन् $9 ९ ९$ पहि, समय अनुसार उपचारहरुलाई दुई बराबर भागमा विभाजन गरिदै लगियो। जस अनुसार $४ \times ३$ बर्ग मिटरको दुई बराबर भागमा आधी भागलाई मूल उपचारको रुपमा राखियो । मूल उपचारहरुको हालको आंकडाले गोठेमलको १० टन प्रति हेक्टरको योगवाट गहुँको उत्पादन २.३ टन प्रति हेक्टरको पाईयो भने, कुनै पानि मल नराखेको उपचारमा सबै भन्दा कम २७७ के जी प्रति हेक्टर उत्पादन भयो । त्यसैगरी, परिमार्जित उपचारमा तत्कालको आंकडा अनुसार गोठेमल १० टन प्रति हेक्टर र रासायानिक मल पू के जी नाईट्रोजन र ४०० के जी पोटासियम प्रतिहेक्टरको संयुक्त प्रयोगले गहुँको २.४ टन प्रति हेक्टर उल्लेखनिय बढ़ी उत्पादन भएको पाइयो । धान-धान-गहुँ प्रणालीमा माटोको पोषक आपूर्तिले नियत्त्रित गहुँमा ३५ औं बर्ष पछि २७७ के.जी. प्रति हेक्टर मात्र गहुँको उत्पादन भयो । हालका बर्षहरुमा नाईट्रोजन, फस्फोरस र पोटासियम नराखेको उपचारमा गहुँको उत्पादनमा धेरैनै कमी आयो। एन. पि. के. र गोठेमल राखेको उपचारहरुमा कुनै एक वा एक भन्दा बढी पोषकतत्व नराखेको उपचारमा भन्दा गहुँको उत्पादन निकै बढी थियो । फस्फोरस र पोटासियमको प्रयोगबाट गहुँको उत्पादनमा कमी आएको देखियो। माटोको गुणमा रासायनिक मलको प्रयोग र खादको महत्वपर्ण प्रभाव थियो। माटोको विश्लेषण आंकडा अनुसार अन्य सबै उपचार संग तुलना गर्दा गोठेमलको प्रयोग गरिएको प्लटहरुमा माटोको पी एच $९ .5$, प्राड़्रारिक पदार्थ ४.१\%, कुल नाईट्रोजन ०.१६, उपलव्ध फस्फोरस ४ू३३.५ र पोटासियम १३७.५ किलो प्रतिहेक्टर रहि सुधारात्मक रहेको पाइयो । नेपालको परिप्रेक्षमा प्राड़ारिक र रासायनिक मलको दिर्घकालिन एकीकृत उपयोगबाट गहुँको उत्पादकत्वमा अभिबृद्धि हुनुका साथै लामो समयको लागि पोषकतत्वमा सुधार हुन् सक्ने निष्कर्ष रहेको देखिन्छ।

\section{INTRODUCTION}

Rice and wheat mostly grown in sequencing order especially in Terai region represents the most important food crops of Nepal. The Terai plain, meets about 75\% of the country's total cereal food demand (NARC 1995). However, productivity and profitability are quite low despite of the fact that a doubling of the crop production in the next 25 years is required to meet Nepal's estimated population growth (NARC 1995, Hobbs and Morris 1996, Kshteri 2010). Increasing the productivity of land through intensive cropping system depletes nutrient reserves of the soil at faster rate (Regmi et al 2003) while unbalanced fertilizer application may disturb nutrient availability to crops, leading to a reduction in yield (Nambiar 1994, Yadav et al 2000). Improving productivity and increasing cropping intensity to sustain yields and meet the future food needs requires adequate soil fertility (Regmi et al 2003). Therefore, to maintain land productivity for crop production, it is likely that new emerging nutrient deficiency or imbalances are addressed, identified and corrected promptly. In such sequence, identification of micronutrients zinc deficiency in rice and boron in wheat represents the best examples (Regmi et al 2003).

It has been observed that continuous use of chemical fertilizers in imbalanced form deteriorates soil physical properties (Biswas et al 1971, Prasad et al 1983, Bhattacharyya et al 2015). Detrimental effects of chemical fertilizers even in balanced form on soil physical properties are also being observed. For example, decline in soil organic carbon and associated decline in system productivity under ricewheat system with the long-term use of recommended NPK was observed in some field studies (Nambiar 1994, Abroal et al 2000, Yadav et al 2000). The widespread stagnation and occasional decline is rice-wheat productivity over the last about three decades have become a matter of serious concern, as rice-wheat is the major cropping system in south Asia, feeding more than 400 million people world-over (Ladha et al 2003). 
Soil fertility is largely attempted to maintain by application of compost and manure, but in recent years a decline in soil fertility has been reported (Shrestha et al 2000). There has been considerable research in Nepal on soil fertility enhancement and soil and water conservation techniques over the years (Keatinge et al 1999, Acharya et al 2000). Despite of that the soil fertility in long run in relation to cropping pattern has always been a subject of interest because of several factors associated including the manure and fertilizer use. Therefore, long-term experiment has always been suggested to be valuable for evaluating the effects of continuous cropping on the capacity of a system to sustain nutrient supply and the productivity (Regmi et al 2003).

For recommending appropriate technologies to maintain soil fertility as well as the environment, it is necessary to evaluate long-term effects of inorganic and organic manures on soil properties (Gami and Sah 1988, Bhattacharya et al 2015). The long-term soil fertility experiments are valuable for understanding the relationships among changing soil, crop management practices and productivity (Bhattacharya et al 2015). It is also important that the data collected from constantly monitoring long-term experiment could be useful for improving statistical and simulation tools (IRRI 2000, Bhattachrayya 2015). Therefore, a long term experiment was initiated under rice-rice-wheat system to evaluate the effects of long term application of mineral fertilizer and organic manure on soil properties and wheat grain yield under rice-rice-wheat system.

\section{MATERIALS AND METHODS}

\section{Experimental Site, Treatments and Crop Management}

The long term experiment was started in 1979/80 at National Wheat Research Program located in Bhairahawa, Rupandehi District in the western Terai Region of Nepal at the latitude of $27^{\circ} 32^{\prime}$ and the longitude of $83^{\circ} 28^{\prime}$ with an elevation of 120 masl. In this site, the air temperature ranges from a minimum of about $7^{\circ} \mathrm{C}$ in winter to the maximum of about $45^{\circ} \mathrm{C}$ in summer. In general, the site receives ample rainfall during the monsoon, which starts from June and continues up to September. The mean annual rainfall is about $1800 \mathrm{~mm}$. The soil of the experiment plot was silty loam with a $\mathrm{pH}$ of 8.0 , organic matter (OM) of $1.783 \%$, P of $9.75 \mathrm{u} / \mathrm{g}$, exchangeable $\mathrm{K}$ of 126 $\mathrm{ug} / \mathrm{g}$ soil and bulk density of $1.6 \mathrm{~g} \mathrm{~cm}^{-3}$ with hard pan just below the plow layer. The soils in the experiment area are classified as Typic Heplaquepts.

The experiment was laid out in randomized complete block design with 9 treatments which were replicated 3 times. The plot size was 6 $\mathrm{x} 4 \mathrm{~m}^{2}$ up to 1990 . From 1990 onwards, periodic modifications have been made in all the treatments splitting the plots in two equal halves of $4 \times 3 \mathrm{~m}^{2}$ leaving one half as original (Table 1). Wheat was sown in rows of $25 \mathrm{~cm}$ apart. Farm yard manure was applied at 710 days before seeding. Half dose of $\mathrm{N}$ and full dose of $\mathrm{P}$ and $\mathrm{K}$ were applied as basal. Remaining $50 \%$ nitrogen was top dressed at $21-$ 25 days after seeding in wheat.

\section{Measurement of Crop Parameters}

Table 1. Original and modified treatments of LTSFE (R-R-W)

\begin{tabular}{|c|c|c|c|}
\hline Tr No & $\begin{array}{l}\text { Original Treatment } \\
\mathrm{N}, \mathrm{P}_{2} \mathrm{O}_{5}, \mathrm{~K}_{2} \mathrm{O} \mathrm{kg} / \mathrm{ha}\end{array}$ & $\begin{array}{l}\text { Modified Tr. (1991) } \\
\mathrm{N}, \mathrm{P}_{2} \mathrm{O}_{5}, \mathrm{~K}_{2} \mathrm{O} \mathrm{kg} / \mathrm{ha}\end{array}$ & $\begin{array}{l}\text { Modified Tr.(1995 onward) } \\
\mathrm{N}, \mathrm{P}_{2} \mathrm{O}_{5}, \mathrm{~K}_{2} \mathrm{O} \mathrm{kg} / \mathrm{ha}\end{array}$ \\
\hline 1 & 0: 0:0 - R \& W & 0: 0:0 - R \& W & 100:50:100- R \& W \\
\hline 2 & 100:0:0- R \& W & $\begin{array}{l}100: 30: 30-\mathrm{R} \\
100: 40: 30-\mathrm{W}\end{array}$ & $\begin{array}{l}100: 30: 30-\mathrm{R} \\
100: 40: 30-\mathrm{W}\end{array}$ \\
\hline 3 & $\begin{array}{l}100: 30: 0-\mathrm{R} \\
100: 40: 0-\mathrm{W}\end{array}$ & $\begin{array}{l}100: 30: 0-\mathrm{R} \\
100: 40: 0-\mathrm{W}\end{array}$ & $\begin{array}{l}100: 30: 30-\mathrm{R} \\
100: 40: 30-\mathrm{W}\end{array}$ \\
\hline 4 & 100:0:30- R \& W & $\begin{array}{l}\text { 100:100:30 } \\
\text { One time - ER }\end{array}$ & $\begin{array}{l}100: 30: 30-\mathrm{R} \\
100: 40: 30-\mathrm{W}\end{array}$ \\
\hline 5 & $\begin{array}{l}100: 30: 30-\mathrm{R} \\
100: 40: 30-\mathrm{W}\end{array}$ & $\begin{array}{l}100: 30: 30-\mathrm{R} \\
100: 40: 30-\mathrm{W}\end{array}$ & $\begin{array}{l}100: 30: 100-\mathrm{R} \\
100: 40: 100-\mathrm{W}\end{array}$ \\
\hline 6 & $\begin{array}{l}100: 0: 0-\mathrm{R} \\
100: 40: 30-\mathrm{W}\end{array}$ & 100:30:0 - ER & $\begin{array}{l}\text { 100:0:0-R } \\
\text { 100:40:30-W } \\
\text { 100:30:0 - ER }\end{array}$ \\
\hline 7 & 50:0:0 - R \& W+ $30 \mathrm{~cm}$ stubble incorporation & 50:20:0 - R \& W +30 cm stb. incorporation & 50:20:0 - R \& W +30 cm stb. incorporation \\
\hline 8 & 50:20:0 - R \& W+ $30 \mathrm{~cm}$ stubble incorporation & $\begin{array}{l}50: 20: 0-\mathrm{R} \& \mathrm{~W}+30 \mathrm{~cm} \text { stubble } \\
\text { incorporation }\end{array}$ & $\begin{array}{l}50: 20: 20-\mathrm{R} \& \mathrm{~W}+30 \mathrm{~cm} \text { stubble } \\
\text { incorporation }\end{array}$ \\
\hline 9 & F Y M 10 t/ha - R \& W & F Y M $10 \mathrm{t} / \mathrm{ha}+50 \mathrm{~kg} \mathrm{~N}-\mathrm{R} \& \mathrm{~W}$ & F Y M $10 \mathrm{t} / \mathrm{ha}+50 \mathrm{~kg} \mathrm{~N}+50 \mathrm{~kg} \mathrm{~K} 20-\mathrm{R} \& \mathrm{~W}$ \\
\hline
\end{tabular}

\section{Soil Sampling and Analysis}

Soil samples were collected from each of the experimental plots after harvesting wheat (5 April 2014). Each soil sample was randomly collected from the 0 to $20 \mathrm{~cm}$ deep plough layer using an auger. For this, the air-dried samples were crushed and passed though a $2 \mathrm{~mm}$ sieve. Soil $\mathrm{pH}$ was determined by a $\mathrm{pH}$ meter after extraction from a soil: water ratio of 1:2. Organic matter was determined using the Walkley and Black dichromate method (Nelson and Sommers 1982) and total N using Kjeldhal's method (Bremner and Mulvaney 1982) For available P determination modified Olsen's (Olson and Sommers 1982 ) methods used; exchangeable K was estimated by $1 \mathrm{M}$ ammonium acetate extraction (Knudsen et al 1982) followed by flame photometric determination. 


\section{Statistical Analysis}

Recorded data were compiled and tabulated in Ms-Excel. Data for each parameter over two year's period was subjected to analysis of variance using a Randomized Complete Block Design according to MSTATC (Steel and Torrie 1980). Treatment means were compared using least significant difference (LSD) test at $P \leq 0.05$.

\section{RESULTS}

Grain yields of wheat in rice-rice-wheat system were affected by the application of different combination of manures and fertilizer treatments.

\section{Original Treatments}

The various growth and yield attributing parameters significantly $(P \leq 0.05)$ differed with the varied use of organic and inorganic sources of nutrients in wheat crop. The plant height, productive tillers per $\mathrm{m}^{2}$, test weight, straw and grain yields were significantly $(P \leq 0.05)$ higher where use of FYM @10 $\mathrm{t} \mathrm{ha}^{-1}$ were applied with the highest yield of $3616 \mathrm{~kg} \mathrm{ha}^{-1}$ in 2011 and $2383 \mathrm{~kg} \mathrm{ha}^{-1}$ in $2012 \mathrm{against}^{2} 25$ $\mathrm{kg} \mathrm{ha}^{-1}$ and $277 \mathrm{~kg} \mathrm{ha}^{-1}$ in control (T1), respectively (Appendix 1, 2 and 3). In 2012/13, logging during heading stage of wheat caused the low yield.

Table 2. Grain yield $\left(\mathrm{kg} \mathrm{ha}^{-1}\right)$ of wheat in LTFT during 2011/12 and 2012/13

\begin{tabular}{cllll}
\hline \multirow{2}{*}{ Trt } & \multicolumn{2}{c}{$\mathbf{2 0 1 1 / 1 2}$} & Original & Modified \\
\cline { 2 - 5 } & Original & Modified & 277 & 1793 \\
T1 & 425 & 3278 & 370 & 1521 \\
T2 & 1218 & 1865 & 333 & 1538 \\
T3 & 1582 & 2124 & 370 & 1682 \\
T4 & 513 & 3176 & 1325 & 1899 \\
T5 & 2622 & 3348 & 1205 & 1418 \\
T6 & 2612 & 2808 & 362 & 1085 \\
T7 & 386 & 1695 & 1064 & 2383 \\
T8 & 1707 & 2524 & 2278 & $*$ \\
T9 & 3616 & 3799 & $* * *$ & 16.4 \\
F test & $* * *$ & $* *$ & 16.6 & 462.2 \\
CV, $\%$ & 25.9 & 21.5 & 223.5 & $*$ \\
LSD $(0.05)$ & 1296 & 1015.8 & $* * *$ & \\
F test & $* * *$ & $* *$ & & \\
\hline
\end{tabular}

LTFT $=$ Long Term Fertility Trial, Trt= Treatments

\section{Modified Treatments}

The highest grain yield (3799 kg ha $\mathrm{kg}^{-1}$ in 2011/12 and $2383 \mathrm{~kg} \mathrm{ha}^{-1}$ in 2012/13) was occurred in treatment-T9 ie FYM @10 t ha ${ }^{-1}+\mathrm{N}$ @ $50 \mathrm{~kg}+50 \mathrm{~kg} \mathrm{~K} 20$, where as application of $\mathrm{N}: \mathrm{P}_{2} \mathrm{O}_{5}: \mathrm{K}_{2} \mathrm{O} @ 50: 20: 0$ plus $30 \mathrm{~cm}$ stubble incorporation gave the lowest grain yield of wheat $\left(1695 \mathrm{~kg} \mathrm{ha}^{-1}\right.$ in $2011 / 12$ and $1085 \mathrm{~kg} \mathrm{ha}^{-1}$ in 2012/12) probably due to absence of $\mathrm{K}$ in the treatment (Table 2). This alarms situation in farmers' field where farmers generally do not apply potassium fertilizer in wheat crop.

\section{Yield Trend of Wheat}

The data revealed that the grain yield of wheat was higher in treatment T9M (FYM $10 \mathrm{tha}^{-1}$ and $\mathrm{N}_{\text {and }} \mathrm{K}_{2} \mathrm{O} 50 \mathrm{~kg} \mathrm{ha}^{-1}$ each which is followed by FYM application alone (T9) and the recommended fertilizer dose (T5). The results showed that yield trends of wheat for $\mathrm{N}$ treatment (T2), NK treatment (T4) and NP treatment (T3) were similar to the control (no-fertilizer) by end of 35 years of the experiment (Figure 1, 2 and 3).

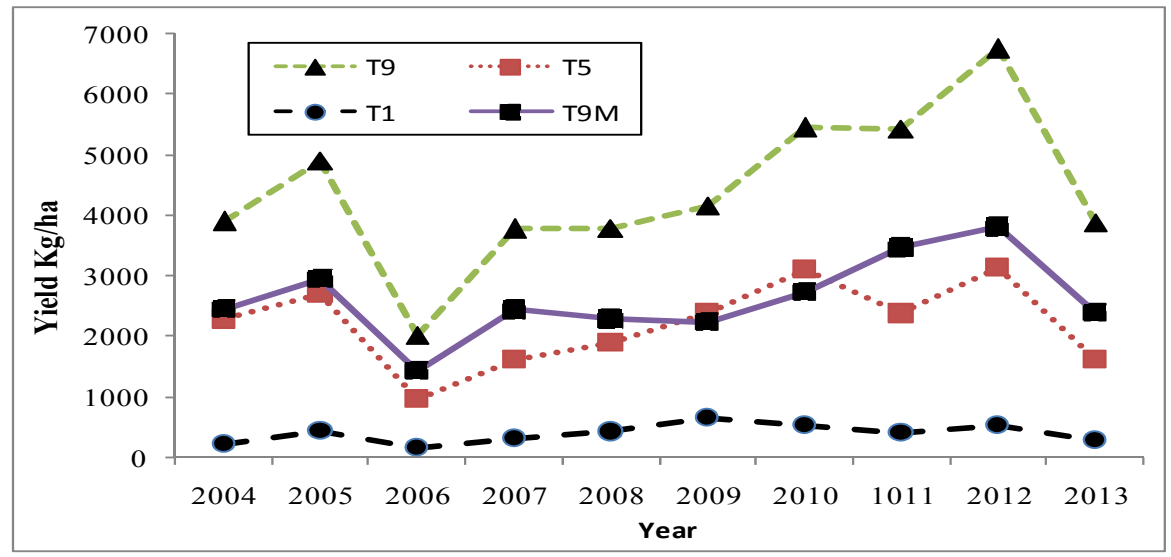

Figure 1. Grain yield trend of long-term application of fertilizers and organic manure on wheat. 


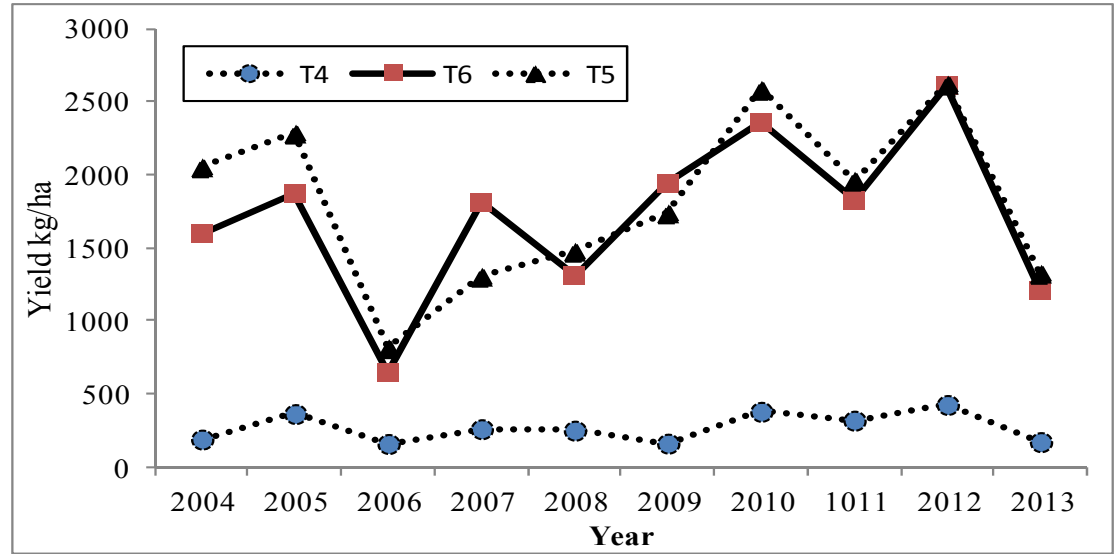

Figure 2. Effect of $\mathrm{P}$ addition on grain yield of wheat.

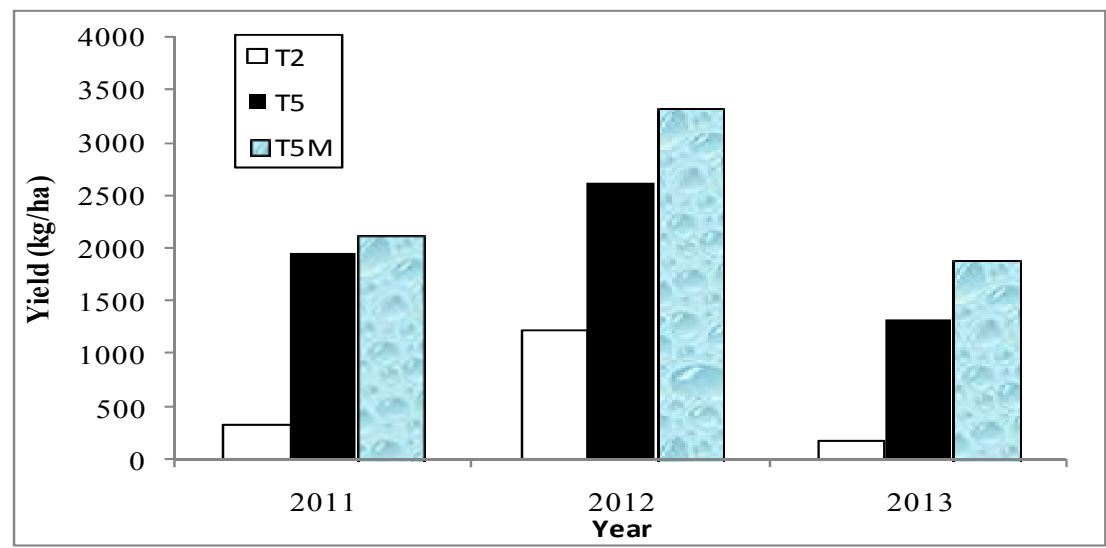

Figure 3. Effect of $\mathrm{P}$ and $\mathrm{K}$ omission on grain yield of wheat.

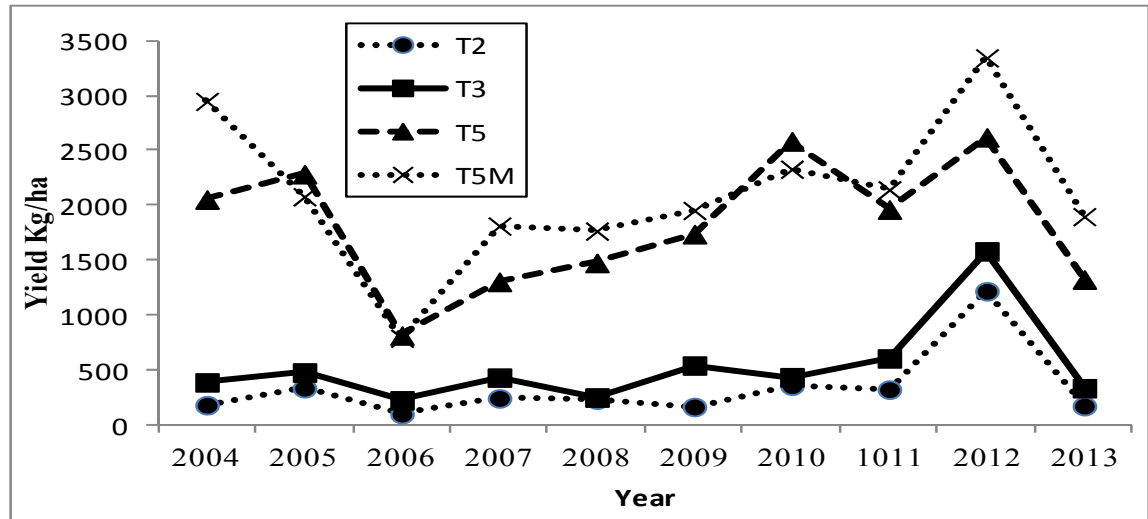

Figure 4. Addition of $\mathrm{K}$ increases wheat yield.

\section{Soil Fertility Status}

There was a significant $(P \leq 0.05)$ effect of manures and fertilizers on soil $\mathrm{pH}$, soil organic matter, $\mathrm{N}$ content, available $\mathrm{P}$ and exchangeable K. At harvest of wheat crop, soil $\mathrm{pH}$ was improved in $\mathrm{T} 9$ (7.87) from the application of farm yard manure as compared to original $(8.0)$ and significantly $(P \leq 0.05)$ higher SOM $(4.12 \%)$ was obtained by applying the FYM and inorganic fertilizer which was statistically similar with the application of FYM alone (4.10\%) (Table 3$)$. Similarly, significantly $(P \leq 0.05)$ higher soil N content was 
obtained from the combined application of FYM $(0.16 \%)$ but it was similar to the application of FYM plus chemical fertilizer $(\mathrm{N}$ and $\left.\mathrm{K}_{2} \mathrm{O}\right)$ and it was the lowest $(1.13 \%)$ in control plot $(0.8 \%)$.

At the end of 35 years experiment, the highest soil available $\mathrm{P}$ of $503.5 \mathrm{~kg} \mathrm{ha}^{-1}$ was occurred in the plots applied with FYM, while the lowest available soil $\mathrm{P}$ of $11.5 \mathrm{~kg} \mathrm{ha}^{-1}$ was in the control plot. Similarly, exchangeable K was significantly $(P \leq 0.05)$ higher $(137.8 \mathrm{~kg}$ ha ${ }^{1}$ ) with $\mathrm{N}$ and $\mathrm{K}_{2} \mathrm{O}$ which was at par with the application of $\mathrm{FYM}$ alone $\left(117.1 \mathrm{~kg} \mathrm{ha}^{-1}\right)$. The soil analysis data showed an improvement in soil $\mathrm{pH}(7.8)$, soil organic matter (4.1\%), total nitrogen content $(0.16 \%)$, available $\mathrm{P}\left(503.5 \mathrm{P}_{2} \mathrm{O}_{5} \mathrm{~kg} \mathrm{ha}^{-1}\right)$ and exchangeable $\mathrm{K}(117.1$ $\mathrm{K}_{2} \mathrm{O} \mathrm{kg} \mathrm{ha}{ }^{-1}$ ) in FYM applied treatments over all other treatments.

Table 3. Soil chemical properties affected by organic \& chemical fertilizers NWRP, Bhairahawa, Nepal

\begin{tabular}{|c|c|c|c|c|c|c|c|c|c|c|}
\hline \multirow[t]{2}{*}{ Treatment } & \multicolumn{2}{|l|}{ pH } & \multicolumn{2}{|c|}{ Organic matter (\%) } & \multicolumn{2}{|c|}{ Nitrogen (\%) } & \multicolumn{2}{|c|}{$\mathrm{P}_{2} \mathrm{O}_{5}\left(\mathrm{~kg} \mathrm{ha}^{-1}\right)$} & \multicolumn{2}{|c|}{$\mathrm{K}_{2} \mathrm{O}\left(\mathrm{kg} \mathrm{ha}^{-1}\right)$} \\
\hline & Original & Modified & Original & Modified & Original & Modified & Original & Modified & Original & Modified \\
\hline $\mathrm{T}_{1}$ & 8.25 & 8.11 & 1.27 & 1.89 & 0.08 & 0.09 & 11.5 & 123.8 & 94.3 & 117.1 \\
\hline $\mathrm{T}_{2}$ & 8.25 & 8.18 & 1.67 & 2.18 & 0.09 & 0.10 & 11.7 & 50.0 & 76.0 & 80.6 \\
\hline $\mathrm{T}_{3}$ & 8.16 & 8.17 & 2.15 & 2.33 & 0.10 & 0.11 & 93.7 & 70.5 & 34.9 & 76.0 \\
\hline $\mathrm{T}_{4}$ & 8.23 & 8.14 & 1.67 & 1.89 & 0.09 & 0.09 & 14.7 & 40.8 & 103.4 & 53.2 \\
\hline $\mathrm{T}_{5}$ & 8.21 & 8.16 & 2.30 & 2.39 & 0.11 & 0.11 & 44.4 & 57.2 & 71.5 & 103.4 \\
\hline $\mathrm{T}_{6}$ & 8.20 & 8.21 & 2.15 & 1.65 & 0.10 & 0.09 & 10.7 & 34.0 & 62.3 & 62.3 \\
\hline $\mathrm{T}_{7}$ & 8.23 & 8.17 & 2.02 & 2.13 & 0.10 & 0.10 & 12.3 & 28.8 & 76.0 & 66.9 \\
\hline $\mathrm{T}_{8}$ & 8.18 & 8.15 & 2.06 & 1.86 & 0.10 & 0.93 & 38 & 34.4 & 71.5 & 76.0 \\
\hline $\mathrm{T}_{9}$ & 7.87 & 7.95 & 4.10 & 4.12 & 0.16 & 0.16 & 503.5 & 403.7 & 117.1 & 137.8 \\
\hline F-test & $* *$ & Ns & $* * *$ & $* *$ & $* * *$ & $* *$ & $* * *$ & $* * *$ & $*$ & $*$ \\
\hline $\operatorname{LSD}(0.05)$ & 0.16 & - & 0.89 & 0.99 & 0.03 & 0.03 & 45.63 & 49.86 & 40.57 & 40.67 \\
\hline $\mathrm{CV}, \%$ & 1.1 & 1.1 & 23.9 & 25.2 & 14.7 & 15.8 & 32.1 & 30.8 & 29.8 & 28.4 \\
\hline $\begin{array}{l}\text { Initial (1978/79 } \\
\text { AD) }\end{array}$ & 8.0 & & 1.025 & & 0.088 & & 9.8 & & 126 & \\
\hline
\end{tabular}

$* * *, * *$ and $*$ denotes significant at $0.1 \%, 1 \%$ and $5 \%$ level of significance respectively and Ns stands for non significant LTFT $=$ Long Term Fertility Trial

\section{DISCUSSION}

Soil fertility and plant nutrient management are key issues to be addressed to understand the reasons for declining crop yields. After 35 years of the experiment, significantly $(P \leq 0.05)$ higher yield of wheat was found in $\mathrm{T} 5, \mathrm{~T} 9$ and $\mathrm{T} 9 \mathrm{M}$ as compared to other treatments (Figure 1). There was fluctuation in grain yield of wheat which could be due to variation in rainfall, temperature, moisture in general during crop growing period. There was very low grain yield in all P missing treatments (T1, T2, T4, and T7) (Figure 1, 2 and 3). This shows $\mathrm{P}$ is one of the most limiting factors for wheat crop. In all treatments in which one or more primary nutrients were lacking, resulted decline in wheat grain yield. This finding was similar to many other studies earlier reported (Dawe and Dobermann 1999, Hobbs and Morris 1996). These implying either the changes in biochemical and physical composition of soil organic matter (SOM) might resulted in gradual decline in the supply of soil nutrients to crop due to inappropriate fertilizer applications causing nutrient imbalances (macro and micro) (Paroda et al 1994).

The grain yield of wheat was found higher in T5 (100:30:30 - R and 100:40:30 - W) followed by T6 (100:0:0 - R and 100:40:30 - W). The significant $(P \leq 0.05)$ differences in grain yield were seen between the $\mathrm{N}: \mathrm{P}_{2} \mathrm{O}_{5}: \mathrm{K}_{2} \mathrm{O}$ and $\mathrm{N}: \mathrm{P}_{2} \mathrm{O}_{5}$ treatments, indicating that the yield reductions in this experiment were also due to the $\mathrm{K}$ deficiency. With the increase in $\mathrm{K}$ level, there was increase in the grain yield of normal wheat (Figure 4).

Proper use of chemical fertilizers and organic manures supports increased agricultural productivity and at the same time, helps maintain soil fertility (Gami and Sah 1988). Similar results have been revealed in present study. The results showed that neither the present dose of $\mathrm{N}: \mathrm{P}_{2} \mathrm{O}_{5}: \mathrm{K}_{2} \mathrm{O}$ nor FYM can sustain productivity in such system. These results corroborate those of Flinn and De Datta (1984), who reported a yield decline under the full recommended dose of fertilizer. In many fertilizer experiments, Nambiar and Abrol (1989) have also found a declining trend with adequate NPK. FYM alone could not supply N and K requirement of wheat crop. The yield increase with the modified (T9M) possibly resulted from replacement of the original (T9) due to balance dose of $\mathrm{N}_{2} \mathrm{P}_{2} \mathrm{O}_{5}: \mathrm{K}_{2} \mathrm{O}$ and other micronutrients contained in FYM.

In the long run, soil fertility is not sustained from the balanced fertilizer application alone while application of FYM helps to boost up crop yield (Lal and Mathur 1989, Kabeerthumma et al 1993) and improve physical soil status (Lal and Mathur 1989b, Kumar and Tripathi 1990). Declining yield trend at lower N level over the years may indicate the diminishing supply capacity of soil. The single greatest cause of declining crop production is unbalanced fertilization (Rattan and Singh 1997). Unbalanced fertilizer application has led to a chronological emergence of macronutrients such as phosphorus and potash (P and $\mathrm{K}$ ) and micronutrients such as zinc, sulfur and manganese (Zn, S and Mn) deficiencies. Even balanced application of macronutrients devoid of organic materials has been implicated in the deterioration of the physical, chemical and biological health of soil (Rattan and Singh 1997).

Our findings also showed that the regular application of FYM might significantly increase the available phosphorus, total nitrogen and carbon contents in the soil but not the potassium level (Table 3). The five-year long-term experiment clear showed that the recommended chemical fertilizer dose of 100:40:30 (N: $\left.\mathrm{P}_{2} \mathrm{O}_{5}: \mathrm{K}_{2} \mathrm{O}\right) \mathrm{kg} \mathrm{ha}^{-1}$ for wheat crop seems to be inadequate for boosting yield and soil productivity. Long-term application of FYM @ 10-tons ha ${ }^{-1}$ was found to enhance its yield and increased the soil nutrients content in the soil. Balanced application is considered a sustainable way of enriching soil and hence restoring its fertility over time (Bhattachryya et al 2015). Similar long term fertility experiments showed that depletion of soil nutrients caused by years of intensive cropping is a common feature that appears to contribute to the observed yield decline (Regmi 1996, Yadvinder-Singh et al 2000). In 
addition to mining of nutrients, there is some evidence of changes in the availability of nutrients to the plant. In most rice-wheat experiments, the soil organic matter declines over time, but, it is not only the decline per season; there may also be changes in the chemical composition of organic matter (Olk et al 1996, 1998, Bronson and Hobbs 1998) that influence the capacity to supply nutrients to the plant. A sustainable fertilizer management strategy must ensure high and stable overall productivity and sufficient nutrient supply for potential yield increases.

The control plot with an indigenous nutrient supply only supported wheat yield of $277 \mathrm{~kg} \mathrm{ha}^{-1}$ in long term experiments of rice-ricewheat system (Figure 1). FYM alone could not supply N and K requirement of wheat crop. The increase in wheat yield was observed due to the application of $50 \mathrm{~kg} \mathrm{ha}^{-1}$ both $\mathrm{N}$ and $\mathrm{K}_{2} \mathrm{O}$ to FYM treatment. The lowest grain yield of wheat may be due to absence of potassium in the treatment. This alarms situation in farmers' field where farmers generally do not apply potassium fertilizer in wheat crop. The soil analysis data showed an improvement in soil $\mathrm{pH}$, soil organic matter, total nitrogen content, available phosphorus and exchangeable potassium in FYM applied treatments over all other treatments. Declining yields and soil nutrient balance in a long-term rice-rice-wheat study suggest depletion of soil potassium $(\mathrm{K})$ and $\mathrm{P}$ fertilization seem to be primary reasons for limited and declining crop yields. The findings showed that the productivity of the wheat can be increased and sustained by improving nutrient through the integrated use of organic and inorganic manures in long term.

\section{ACKNOWLEDGMENTS}

We would like to thank the Wheat Coordinator, NWRP, Bhairahawa for providing facilities and proper guidance during the course of this research. Funding for the long term research was obtained from Nepal Agricultural Research Council.

\section{REFERENCES}

Abroal IP, KF Bronson, JM Duxbury and RK Gupta. 2000. Long term soil fertility experiments in rice-wheat cropping systems. In: Rice-wheat Consortium Paper Series No. 6. Rice-wheat Consortium for the Indo-Gangetic Plains. New Delhi, India.

Acharya GP, BP Tripathi, SP Shrestha and PJ Gregory. 2000. Nutrient management in maize-finger millet systems in the hills of Nepal. Lumle Seminar Paper No. 2000/8. Agriculture Research Station Lumle, Pokhara, Nepal.

AP Regmi, JK Ladha, H Pathak, E Pasuquin, C Bueno, D Dawe, PR Hobbs, D Joshy, SL Maskey, and SP Pandey. 2003. Yield and Soil Fertility Trends in a 20-Year Rice-Rice-Wheat Experiment. Better Crops International. 17:31.

Bhattacharyya P, Nayak AK, Shahid M, Tripathi R, Mohanty S, Kumar A, Rajagounder R, Panda B B, Lal B, Gautam P, Swain CK, Singha RK, Dash P K (2015) Effects of 42-year long-term fertilizer management on soil phosphorus availability, fractionation, adsorption-desorption isotherm and plant uptake in flooded tropical rice. The Crop Journal, Available online at www.sciencedirect.com

Biswas TD, BL Jain and SC Mandal. 1971. Cumulative effect of different levels of manures on the physical properties of soil. J. Indian Soc. Soil Sci. 19:31-37.

Bremner JM and CS Mulvaney. 1982. Nitrogen Total. In: Page AL, Miller RH, Keeney DR (eds) Method of soil analysis. Chemical and microbiological properties. Agronomy no. 9. Part 2, $2^{\text {nd }}$ ed. ASA\& SSSA, Madison, WI. Pp.595-622.

Bronson KF, Hobbs PR. 1998. The role of soil management in improving yields in the rice-wheat systems of South Asia. In: Lal R, editor. Soil quality and agricultural sustainability. Chelsea, Mich. (USA): Ann Arbor Press. Pp.129-139.

Dawe D and A Dobermann. 1999. Defining productivity and yield. IRRI discussion paper series no. 33. Manila (Philippines): International Rice Research Institute, Los Banos, Philippines.

Flinn JC and SK Detta. 1984. Trends in irrigated rice yields under intensive cropping at Philippine research station. Field Crops Research. 9:1-15.

Gami SK and MP Sah. 1998. Long term soil fertility experiment under rice-wheat cropping system. In: Proceedings of first national workshop on long-term soil fertility experiments (11-13 August 1998). (Eds. SL Maskey, BP Tripathi, AP Regmi, JK Tuladhar and B Adhikari). Soil Science Division, Nepal Agricultural Research Council, Khumaltar. Pp.12-28.

Hobbs P and M Morris. 1996. Meeting South Asia's future food requirements from rice-wheat cropping systems: priority issues facing researchers in the post-green revolution era. Natural Resources Group (NRG) Paper 96-01, CIMMYT, Mexico.International Rice Research Institute (IRRI). 2005. IRRISTAT for Windows, Ver. 5.0. Los Banos, Philippines.

Kabeerathumma S, CR Mohankumar, GM Nair and PG Nair. 1993. Effect of continuous cropping of cassava with organics and inorganics in the secondary and micronutrient elements status of an Ultisol. J. Indian Soc. Soil. Sci. 41:710-713.

Keatinge JDH, A Qui, TR Wheeler, M Subedi, PB Shah, RH Ellis and RJ Summerfield. 1999. Annual legume species as green manures/cover crops in low income farming systems of Nepal. Mountain Res. Develop. 19:325-332.

Knudsen D, GA Peterson and PF Pratt. 1982. Lithium, sodium and potassium. In: Page AL, Miller RH, Keeney DR (eds.) Method of soil analysis, chemical and microbiological properties. ASA \&SSSA, Madison. Pp.228-238.

Kumar A and RP Tripathi. 1990. Effect of continuous use of manure and fertilizer on physical properties of soil under paddy-wheatcowpea cropping system. Crop Res. 3(1):7-13.

Ladha JK, JE Hill, JM Duxbury, RK Gupta and RJ Buresh. 2003. Improving the Productivity and Sustainability of Rice-wheat System: Issues and Impacts. ASA Spl. Publ. 65.

Lal S and BS Mathur. 1989a. Effect of long-term fertilization manuring and liming of an Alfisol on maize, wheat and soil properties-I. Maize and wheat. J. Indian Soc. Soil Sci. 37: 17-724.

Nambiar RKM and IP Abrol. 1989. Long-term fertilizer experiments in India: An overview. Fertilizer News. 34:11-20.

Nambiar KKM. 1994. Soil fertility and crop productivity under long- term fertilizer use in India. Indian Council for Agricultural Research, New Delhi, India.

Nelson DW and LE Sommers. 1982. Total carbon, and organic carbon, and organic matter. In: Page AL (ed.) Method of soil analysis, chemical and microbiological properties. ASA \& SSSA, Madison. Pp.539-579. 
Nepal Agricultural Research Council (NARC). Nepal Agricultural Research Council. 1995. Agricultural Statistics of Nepal 1994/95. NARC, Khumaltar, Nepal, India.

Olk DC, Cassman KG, Mahieu N, Randall EW. 1998. Conserved chemical properties of young soil humic acid fractions in tropical lowland soils under intensive irrigated rice cropping. Eur. J. Soil Sci. 49:337-349.

Olk DC, Cassman KG, Randall EW, Kinchesh P, Sanger LJ, Anderson JM. 1996. Changes in chemical properties of soil organic matter with intensified rice cropping in tropical lowland soils. Eur. J. Soil Sci. 47:293-303.

Olson SR, LE Sommers. 1982. Phosphorus. In: Page AL, Miller RH, Keeney DR (eds) Method of soil analysis. Chemical and microbiological properties. ASA \&SSSA, Madison. Pp.430.

Paroda RS, T Woodhead and RB Singh. 1994. Sustainability of rice-wheat production systems in Asia. Rapa Publication. (FAO), no. 1994/11. FAO Regional Office for Asia and Pacific, Bangkok, Thailand.

Prasad B, RP Singh, HK Roy, H Sinha. 1983. Effect of fertilizer, lime and manure on some physical and chemical properties of a red loam soil under multiple cropping. J. Indian Soc. Soil Sci. 31:601-603.

Rattan RK and AK Singh. 1997. Role of balanced fertilization in rice-wheat cropping system. Fertilizer News 42:79-97.

Regmi AP. 1991. Long-term fertility trial under rice-rice-wheat rotation. Paper presented at the $14^{\text {th }}$ Winter Crop Seminar, Khumaltar, Nepal.

Regmi AP. 1996. Long-term soil fertility trial under rice-wheat rotation. Paper presented at National Winter Crops Technology Workshop, 7-10 September 1995, Khumaltar, Nepal.

Shrestha B, SL Maskey, RK Shrestha, BP Tripathi, YG Khadka, RC Munankarmi, EM Bhattarai and SP Shrestha. 2000. Soil fertility management: farmers' practices and perception in the hills of Nepal. Lumle Technical Paper No. 2000/4. Lumle Agriculture Research Station, Pokhara, Nepal.

Singh Y, A Dobermann, Singh B, KF Bronson, CS Khind. 2000. Optimal phosphorus management strategies for wheat-rice cropping on a loamy sand. Soil Sci. Soc. Am. J.

Steel RGD and JH Torrie. 1980. Principles and Procedures of Statistics McGraw Hill Book Co. Inc., NY.

Thapa K. 2010. On-farm management and quality assessment of farmers' saved wheat seed in the western Terai, Nepal, Agronomy Journal of Nepal 1:50-60.

Yadav RL, BS Dwivedi and PS Pandey. 2000. Rice-wheat crop ping system: Assessment of sustainability under green manuring and chemical fertilizer inputs. Field Crops Res. 65: 15-30. 


\section{APPENDIXES}

Appendix 1. Rating chart of soil values to determine the fertility status of experimental soil

\begin{tabular}{llll}
\hline Nutrient & Low & Medium & High \\
\hline Available $\mathrm{N}(\%)$ & $<0.10$ & $0.1-0.2$ & $>0.2$ \\
Available $\mathrm{P}_{2} \mathrm{O}_{5}(\mathrm{~kg} / \mathrm{ha})$ & $<30$ & $30-55$ & $>55$ \\
Available $\mathrm{K}_{2} \mathrm{O}(\mathrm{kg} / \mathrm{ha})$ & $<110$ & $110-280$ & $>280$ \\
Organic matter $(\%)$ & $<2.5$ & $2.5-5.0$ & $>5.0$ \\
$\mathrm{pH}$ & $<6.0$ (Acidic) & $6.0-7.5$ (Neutral) & $>7.5($ Alkaline) \\
\hline
\end{tabular}

Source: Khatri Chettri 1991 and Jaishy 2000

Appendix 2. Plant height, productive tillers $/ \mathrm{m}^{2}, 1000$-grain weight, straw yield and grain yield of wheat in LTFT conducted at NWRP, Bhairahawa, 2011/12

\begin{tabular}{|c|c|c|c|c|c|c|c|c|c|c|}
\hline \multirow{2}{*}{ Trt } & \multicolumn{2}{|c|}{ Plant height, cm } & \multicolumn{2}{|c|}{ Tillers/m² (n) } & \multicolumn{2}{|c|}{ 1000-grain weight (g) } & \multicolumn{2}{|c|}{ Straw yield $\left(\mathrm{kg} \mathrm{ha}^{-1}\right)$} & \multicolumn{2}{|c|}{ Grain yield $\left(\mathrm{kg} \mathrm{ha}^{-1}\right)$} \\
\hline & Original & Modified & Original & Modified & Original & Modified & Original & Modified & Original & Modified \\
\hline $\mathrm{T}_{1}$ & 66.33 & 100.87 & 187.7 & 220.3 & 30.53 & 42.40 & 1722 & 7611 & 425 & 3278 \\
\hline $\mathrm{T}_{2}$ & 59.87 & 93.20 & 167.3 & 225.0 & 23.07 & 38.75 & 1389 & 6778 & 1218 & 1865 \\
\hline $\mathrm{T}_{3}$ & 91.77 & 87.80 & 237.3 & 214.3 & 35.73 & 32.73 & 6389 & 5222 & 1582 & 2124 \\
\hline $\mathrm{T}_{4}$ & 64.90 & 96.47 & 206.3 & 255.3 & 29.20 & 37.07 & 1722 & 7389 & 513 & 3176 \\
\hline $\mathrm{T}_{5}$ & 94.70 & 99.47 & 229.7 & 234.3 & 36.87 & 41.57 & 6389 & 7389 & 2622 & 3348 \\
\hline $\mathrm{T}_{6}$ & 94.13 & 95.10 & 237.3 & 230.0 & 40.40 & 38.13 & 6222 & 6444 & 2612 & 2808 \\
\hline $\mathrm{T}_{7}$ & 60.90 & 83.03 & 163.3 & 221.3 & 26.33 & 35.47 & 1278 & 3444 & 386 & 1695 \\
\hline $\mathrm{T}_{8}$ & 81.87 & 92.37 & 199.0 & 230.7 & 31.00 & 41.07 & 3500 & 4778 & 1707 & 2524 \\
\hline $\mathrm{T}_{9}$ & 97.53 & 100.03 & 228.0 & 239.7 & 44.07 & 45.33 & 8167 & 8833 & 3616 & 3799 \\
\hline F test & $* * *$ & $* *$ & $* *$ & Ns & $* * *$ & $* *$ & $* * *$ & $* * *$ & $* * *$ & $* *$ \\
\hline $\mathrm{CV}$ & 4.4 & 5.0 & 10.8 & 12.1 & 7.0 & 8.1 & 14.1 & 13.6 & 25.9 & 21.5 \\
\hline LSD & 6.032 & 8.237 & 38.71 & 48.36 & 3.986 & 5.519 & 997.4 & 1510.4 & 1296 & 1015.8 \\
\hline
\end{tabular}

$* * *, * *$ and $*$ denotes significant at $0.1 \%, 1 \%$ and $5 \%$ level of significance respectively and Ns stands for non significant

LTFT $=$ Long Term Fertility Trial, GY= Grain Yield, Trt= Treatments

Appendix 3. Plant height, productive tillers $/ \mathrm{m}^{2}$ test weight, straw yield and grain yield of wheat per hectare in LTFT conducted at NWRP, Bhairahawa, 2012/13

\begin{tabular}{|c|c|c|c|c|c|c|c|c|c|c|}
\hline \multirow[t]{2}{*}{ Trt } & \multicolumn{2}{|l|}{ PH } & \multicolumn{2}{|c|}{ spikes $/ \mathbf{m}^{2}$} & \multicolumn{2}{|c|}{ 1000-grain wt. } & \multicolumn{2}{|l|}{ Biomass } & \multicolumn{2}{|c|}{ Grain yield $\left(\mathrm{kg} \mathrm{ha}^{-1}\right)$} \\
\hline & Original & Modified & Original & Modified & Original & Modified & Original & Modified & Original & Modified \\
\hline $\mathrm{T}_{1}$ & 65.00 & 91.33 & 144 & 176.7 & 28.81 & 32.48 & 1111 & 4389 & 277 & 1793 \\
\hline $\mathrm{T}_{2}$ & 58.00 & 83.67 & 163 & 207.3 & 25.27 & 26.29 & 889 & 4000 & 370 & 1521 \\
\hline $\mathrm{T}_{3}$ & 66.67 & 84.44 & 134 & 196.0 & 19.81 & 27.36 & 1278 & 4278 & 333 & 1538 \\
\hline $\mathrm{T}_{4}$ & 59.67 & 83.67 & 130 & 180.0 & 30.14 & 28.23 & 1000 & 43.89 & 370 & 1682 \\
\hline $\mathrm{T}_{5}$ & 82.67 & 91.67 & 205 & 179.7 & 31.00 & 30.17 & 3778 & 6944 & 1325 & 1899 \\
\hline $\mathrm{T}_{6}$ & 83.33 & 82.00 & 171 & 161.7 & 27.79 & 27.42 & 3444 & 3278 & 1205 & 1418 \\
\hline $\mathrm{T}_{7}$ & 55.67 & 77.00 & 132 & 183.3 & 27.19 & 25.99 & 889 & 2878 & 362 & 1085 \\
\hline $\mathrm{T}_{8}$ & 84.67 & 89.67 & 156 & 221.3 & 27.07 & 31.92 & 2556 & 3711 & 1064 & 1709 \\
\hline $\mathrm{T}_{9}$ & 90.00 & 95.67 & 215 & 220.3 & 38.19 & 30.77 & 6000 & 6600 & 2278 & 2383 \\
\hline F-test & $* * *$ & $* *$ & $* *$ & Ns & $* * *$ & Ns & $* * *$ & Ns & $* * *$ & $*$ \\
\hline $\mathrm{CV}, \%$ & 4.4 & 3.1 & 16.3 & 17.0 & 7.2 & 9.2 & 11.5 & 33.9 & 16.6 & 16.4 \\
\hline LSD & 5.41 & 4.64 & 45.51 & 56.40 & 3.55 & 4.63 & 462.0 & 3351.7 & 223.5 & 462.2 \\
\hline
\end{tabular}

$* * * * *$ and $*$ denotes significant at $0.1 \%, 1 \%$ and $5 \%$ level of significance respectively and Ns stands for non significant

LTFT $=$ Long Term Fertility Trial, Trt $=$ Treatments 